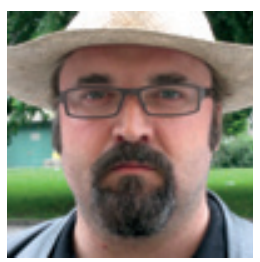

\title{
Gjøkungen i medisinen
}

\section{2009 gikk jeg hardt ut mot psykiatri og legemiddelindustri i norske medier. Dette skapte til tider stor furore, og mange ærlige helsearbei- dere følte seg nok litt tråkket på av mine krasse uttalelser om uetikk, lov- brudd og menneskerettighetsbrudd i den mentale helsesektoren.}

La det være klinkende klart: Uetikken, lovbruddene og menneskerettighets-bruddene i denne sektoren er store. Jeg angriper absolutt ikke den ærlige helsearbeiders ønske om å gjøre en god, etisk og lovlydig jobb i denne sektoren. Problemet slik jeg opplever det, er at det i den somatiske helsesektoren har sneket seg inn en gjøkunge som får herje fritt - uten at noen egentlig konfronterer den. Det er kunnskapen om dette problemet vi i CCHR ønsker å spre til helsearbeidere og andre berørte. Samtidig som vi nådeløst anmelder og forfølger ethvert lov- og menneskerettsbrudd vi oppdager i vårt arbeid i den mentale helsesektoren.

Gjøkungen som har begynt å regjere, særlig på fastlegekontoret, heter psykiatri. Fastlegens jobb har endret seg mye de siste 30 årene. Tidligere gikk man til sin lege og søkte hjelp når man ble syk. Legens jobb var og er å foreta vitenskapelige, objektive tester, fastsette diagnoser på sykdommer og kurere disse sykdommene. Det nye scenarioet på fastlegekontoret er ikke fullt så vitenskapelig. Kommer en pasient til sin lege i dag og har en emosjonell lidelse, begynner et spill som tilsynelatende har noe med medisin å gjøre, men som i virkeligheten handler om salg av legemidler. En vanlig fastlege forventes å skulle diagnostisere normale menneskelige tilstander som depresjon, søvnløshet, angst og avhengig- heter som sykdommer på lik linje med fysiske sykdommer, og behandle disse med medikamenter.

I stedet for reelle vitenskapelige tester, må legen ty til en diagnosemanual som for eksempel den amerikanske DSM (Diagnostic Statistic manual of Mental disorders) utgitt av den amerikanske psykiatriforeningen APA. Diagnosene der er stemt inn av et råd av psykiatere og psykologer, og det blir vedtatt ved avstemming at disse er sykdommer. Samtidig står de internasjonale farmasiselskapene klare med $8-10$ preparater som lanseres for akkurat denne nye sykdommen. Det finnes ingen vitenskapelige tester for å påvise at en mental/emosjonell lidelse er en sykdom. Diagnosene blir altså funnet opp, og forklaringene som gis er høyst upåviselige. Det eksisterer for eksempel en allmenn oppfatning om at en psykiatrisk sykdom skyldes en nevrokjemisk ubalanse i hjernen, og det er akkurat denne ubalansen et psykiatrisk preparat skal behandle. Og det er ikke lenger bare psykiatere som foretar disse diagnostiseringene. I $70 \%$ av tilfellene der en pasient får tildelt en psykiatrisk diagnose og skrevet ut psykofarmaka i dag, er det fastlegene som står for behandlingen. Flere og flere fastleger stiller seg nå kritiske til denne nye praksisen. Farmasiselskapene øver et ekstremt press på den enkelte lege for å få ham til å skrive ut deres preparater. Selv om myndighetene forsøker å regulere situsjonen med kickbacks og bonuser, foregår markedsføringen for fullt i det norske helsevesenet.

På den andre siden står det massive kravet fra den enkelte pasient om å få akkurat sin emosjonelle tilstand diagnostisert som en reell sykdom, slik at han skal kunne få medikamenter og få ha sine pasientrettigheter. Ofte kommer pasienten med en fiks ferdig diagnose til sin lege, og forventer kun legens underskrift på resept og sykmelding. Sym- ptomene han beskriver virker påfallende lik diagnosebeskrivelsen i DSM, eller i artikler i legetidsskrifter. Informasjon hentet direkte, eller via omveier, fra produsenten av preparatet han ønsker utskrevet. Veldig ofte er pasientstøttegrupper for disse diagnosene kilder til det pasienten ber om av sin lege. Det viser seg ofte at ledelsen og fagkompetensen i disse gruppene består av nettopp psykiaterne som arbeider i dette feltet, og finansieringen av gruppene kommer direkte fra produsenten av preparatene til disse enkeltdiagnosene. I Norge har søkelyset spesielt vært rettet mot foreningen ADHD Norge, som får mye av sin økonomiske støtte fra produsentene av Ritalin, Concerta og Stratera. Vi i CCHR Norge er kontinuerlig i kontakt med politi, fagmiljø og medier for å belyse dette forholdet.

Fastlegene bør spørre seg om de lenger vil være redskaper for psykiatriens og legemiddelindustriens massive markedsføring av pseudovitenkapelige diagnoser og psykiatrisk farmasi. Noen stabile data bør en somatisk lege kunne forholde seg til:

- Psykiatriske forstyrrelser er ikke reelle sykdommer som krever medisinsk behandling.

- Det finnes ingen bevis i det hele tatt på at psykofarmaka er løsningen på noe psykisk problem.

- Psykofarmaka skjuler symptomer og gir alvorlige bivirkninger på kort og lang sikt.

- Psykofarmaka kan forårsake avhengighet, forverre den mentale og fysiske helsen og være direkte årsak til selvmord, drap og voldelig atferd.

Vi i CCHR oppfordrer fastlegene og annet helsepersonell til å øke sin kunnskap, sitt ansvar og sin handlekraft, og få gjøkungen ut av medisinen.

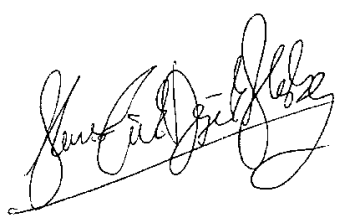

\section{I neste nummer:}

\section{Overgrep og psykisk helse \\ Aldersgrense for leger \\ Seksuelle bivirkninger \\ av antidepressiver}

\section{Smertehemming}

Mammografiscreening

Oppmerksomt nærvær 